\title{
MANAGEMEN PENDIDIKAN TINGGI TANTANGAN DAN PERMASALAHANNYA PADA ABAD KE 21
}

\author{
Kudrat Dukalang \\ Institut Agama Islam Negeri Manado, Sulawesi Utara, Indonesia \\ Kudratdukalang1@gmail.com
}

\begin{abstract}
Globalization that has been going on rapidly since the 1980s has led to very basic social, economic and political changes in all countries. The world of higher education which adheres to universalism in science and technology actually always pays attention and considers that the Indonesian education community is part of a global society. In the next 1015 years, Indonesian universities will face a variety of major challenges that need to be responded wisely. Economic globalization and the information technology revolution is a huge force affecting the world of Indonesian universities.
\end{abstract}

Keywords: Education Management, Challenges, Problems, Globalization

Abstrak. Globalisasi yang sedang berlangsung dengan cepat sejak dekade 1980-an telah menimbulkan perubahan sosial, ekonomi dan politik yang sangat mendasar pada semua negara. Dunia pendidikan tinggi yang menganut faham universialisme ilmu pengetahuan dan teknologi sebenarnya selalu memperhatikan dan mempertimbangkan bahwa masyarakat pendidikan Indonesia adalah bagian dari masyarakat global. Pada kurun waktu 10-15 tahun ke depan, perguruan tinggi Indonesia akan menghadapi berbagai tantangan besar yang perlu di respons dengan bijaksana. Globalisasi ekonomi dan revolusi teknologi informasi merupakan kekuatan yang amat besar mempengaruhi dunia perguruan tinggi Indonesia.

Kata Kunci: Managemen Pendidikan, Tantangan, Permasalahan, Globalisasi 


\section{Pendahuluan}

Berbagai kendala birokrasi, ekonomi dan soaial yang kita hadapi dalam pengelolaan perguruan tinggi sangat membelenggu pemikiranpemikiran yang menjangkau jauh ke depan. Mantan menteri pendidikan Dr. Daoed Joesoef, dalam salah satu tulisannya, menggambarkan bahwa sebagai bangsa kita menderita myopia temporal.Akibatnya, kita tidak mampu memahami masalah-masalah yang dihadapi bangsa dalam perspektif jangka panjang. Sebagai bangsa kita terjebak dalam carut-marut permasalahan saat ini dan lupa bahwa setiap tindakan yang kita lakukan untuk mengatasi permasalah jangka pendek mempunyai dampak positif dan negatif di masa depan.

Karena implikasi tindakan jangka panjang kurang dipertimbangankan, seringkali solusi jangka pendek berkembang menjadi masalah baru pada jangka panjang. Pada kesempatan yang singkat ini saya ingin menyoroti pengelolaan perguruan tingi dalam perspektif temporar jangka panjang tersebut mencoba mengidentifikasi langkah-langkah stratejik untuk menghadapi berbagai tantangan dan hambatan yang akan dihadapi.

Untuk itu, pembahasan pada makalah ini terdapat dalam tiga bagian.

\section{Pembahasan}

Pada pembahasan ini akan menyoroti, pengelolaan perguruan tinggi dalam perspektif temporal jangka panjang tersebut mencoba mendefinisikan langkahlangkah stratejik untuk menghadapi berbagai tantangan dan hambatan yang akan dihadapi.

Untuk itu pembahasan pada makalah ini terdapat tiga bagian. Pada bagian pertama saya akan menguraikan tentang globalisasi serta tantangan bagi perguruan tinggi. Pada bagian kedua, tantangan sosial yang dihadapi perguruan tinggi Indonesia Bagian ketiga, akan di uraikan pengelolaan Universitas Gadjah Mada sebagai perguruan tinggi otonom. Jurnal ini akan diahiri dengan kesimpulankesimpulan dan pelajaran bagi perguruan tinggi. Jurnal ini akan diahiri dengan kesimpulan-kesimpulan dan pelajaran bagi perguruan Iain.

\section{Globalisasi dan Tantangan Perguruan Tinggi.}

Pada kurun waktu 10-15 tahun ke depan, perguruan tinggi Indonesia akan menghadapi berbagai tantangan besar yang perlu di respons dengan bijaksana. Globalisasi ekonomi dan revolusi teknologi informasi adalah kedua kekuatan besar yang amat mempengaruhi dunia perguruan tinggi Indonesia. Kalau lembaga pendidikan tinggi nasional tidak mampu merespons tantangan globalisasi ini dengan memadai, diperkirakan lembaga tersebut akan tidak mampu mempertahankan eksistensinya di masyarakat dan secara pelan tetapi pasti akan kehilangan peranannya. Mudahmudahan ramalan yang pesimitis ini tidak perlu terjadi asal kita mampu mengembangkan strategi-strategi survival yang tepat.

Dunia pendidikan tinggi yang menganut faham universalisme ilmu pengetahuan dan teknologi sebenarnya selalu memperatikan dan mempertimbangkan bahwa masyarakat pendidikan Indonesia adalah bagian dari masyarakat global.

Proses seperti ini oleh Beck disebut globalitas yang sudah berlangsung sejak lama dalam dunia pendidikan mau pun 
dalam perdagangan international.Tetapi dalam perkembangan yang terjadi sejak 1970an globalisasi berkembang menjadi "the process through which sovereign national states are criss-crossed and undermined by transnational actorsgovernments or MNCs- with varying prospect of power, orientations, identities, and networks".

Menentukan adalah kemajuan atau bahkan revolusi teknologi khususnya dalam teknologi informasi dan bioteknologi yang dikuasai oleh perusahaanperusahaan yang memiliki menugasai modal financial dan intelektual.Restrukturisasi sosial-ekonomi yang terjadi di Negara-negara maju pada kurun waktu 1980an terjadi karena didorong oleh 2 kekuatan besar yakni kemajuan teknologi informasi dan keputusan perusahaan yang menguasai modal besar. Pada kondisi seperti ini ilayah suatu Negara berdaulat akan mengalami perubahan mendasar dalam substrukturnya. Di masa lalu suatu bangsa selalu memiliki dan menguasai baik superstruktur dan substruktur sehingga keduanya terpisah dan dapat dibedakan dari bangsa lain. Tetapi dalam era globalisasi, superstrukturpemerintah-tidak sepenuhnya berdaulat atas suatu Negara. Substruktur suatu bangsa yang sekarang mencakup MNCs mempunyai "kekuatan" yang luar biasa untuk memaksa pemerintah Negara "berdaulat" untuk melaksanakan kehendaknya. Ironisnya, proses yang disebut sebagai penjajahan kulit putih oleh Prof. T. Jacob, terjadi dengan dukungan lembaga-lembaga International seperti IMF, Bank Dunia dan bahkan PBB yang pada era globalisasi ini cenderung lebih membela kepentingan Negara superpower daripada Negara berkembang yang dikucilkan. Terlepas dari ketidaksetujuan kita terhadap cara-cara
Presiden Saddan Hussein memimpin Iraq, kampanye perang yang dilancarkan oleh Amerika Serikat saat ini dengan dukungan PBB merupakan salah satu contoh dari implikasi negatif globalisasi dalam politik International.

Sebagai lembaga sosial yang secara tradisional bertugas mengembangkan ilmu pengetahuan dan teknologi, perguruan tinggi adalah lembaga yang paling merasakan tuntutan sosial untuk perubahan global tersebut. Dunia usaha, pemerintah dan masyarakat yang memerlukan ilmu pengetahuan baru yang berbasis teknologi informasi, bioteknologi serta ilmu-ilmu multidisiplin lainnya akan menuntut perguruan tinggi untukmemenuhi kebutuhan mereka akan ilmu pengetahuan dan teknologi yang lebih tinggi. Globalisasi ekonomi yang sedang berlangsung dengan cepat pada beberapa decade ke depan, disatu fihak akan memberika kesempatan yang amat besar kepada perguruan tinggi untuk memberikan pelayanan ilmu pengetahuandan teknologi baik kepada pemerintah, masyarakat maupun kepada dunia usaha. Tetapi kalau perguruan tinggi terlalu terjerumus pada kegiatan tersebut, peranan perguruan tinggi selama ini yanghampir monopolistic dalam pengembangan ilmu pasti akan mengalami perubahan drastis. Yang tidak kalah pentingnya untuk selalu diperhatikan adalah peranan perguruan tinggi Indonesia sebagai lembaga menghasilkan calon pemimpin bangsa yang bermoral dan berbudaya demokratis. Kalau perguruan tinggi terlalu terjebak dalam arus globalisasi yang merupakan suatu proses yang nir-demokratis, secara pasti perguruan tinggi akan tidak mampu melaksanakan salah satu tugas utamanya tersebut. 


\section{Perubahan Dan Tantangan Perguruan Tinggi Indonesia}

Globalisasi yang sedang berlangsung dengan cepat sejak decade 1980-an telah menimbulkan perubahan sosial, ekonomi dan politik yang sangat mendasar pada semua negara. Deklarasi Bogor yang menyatakan bahwa Indonesia akan ikut serta dalam percaturan perdagangan bebas diwilayah Asia dan pasifik (AFTA)tanpa struktur ekonomi yang kuat ternyata telah manjerumuskan Indonesia ke dalam krisis ekonomi yang parah sejak 1998. Globalisasi perdagangan ini telah membawa implikasi positif maupun negative yang amat besar pada dunia perguruan tinggi kita baik dakam pembiayaan, populasi calon mahasiswa serta perubahan peranan perguruan tinggi.Perubahan iniharus direspons dengn baik oleh perguruan tinggi agar dapat tetap memainkan peranan pentingnya dalam masyarakat Indonesia. Perubahan yang terpenting adalah:

a. Pembiayaan pemerintah untuk pendidikan tinggi akan semakin berkurang

b. Perubahan populasi calon mahasiswa

c. Disparitas antar daerah

Pembiayaan pemerintah untuk pendidikan tinggidengan judul yang agak provokativ "The Gloom Over Britain's Universities", majalah The Economist edisi November 2002 menampilkan cover story tentang pendidikan tinggi di ingris. Dunia pendidikan tinggi ingris, seperti negara eropa lainnya, sejak decade 2000-an memang sedang menghadapi kondisi keuangan yang amat berat. Di satu pihak birokrasi pendidikan yang amat sentralistis menetapkan target nasional diukur dari partisipasi pendidikan tinggi sebesar 35 persen. Tetapi di lain pihak pemerintah tidak bersedia meningkatkan anggaran pendidikan tinggi. Kalau masalah besar ini terus tanpa ada upaya Pemerintah untuk mengatasinya, maka kata mantan Menteri Pendidikan Inggris, Lord Baker, dunia pendidikan tinggi inggris pasti akan bangkrut. Kata beliau lebih lanjut, "when great institutions decline they do not suddenly fall over a precipice, the simply slide down the slope, a little further each year, in a genteel way, making do in their reduced circumstances, like a spinster in an Edwardian novel". Jangan tanyakan saya mengapa Lord Baker mempersamakan perguruan tinggi dengan perawan tua.Mungkin perawan tua di inggris harus selalu hidup serba kekurangan selama hayat sampai ajal datang menjemput. Dengan tamsil itu Lord Baker mungkin ingin menyampaikan bahwa perguruan tinggi inggris akan mengalami nasib yang sama dengan perawan tua kalau pemerintah inggris tidak berani mengambil tindakan drastic yang pasti tidak popular, yakni menerapkan pembiayaan pendidikan tinggi yang lebih rasional.

Perguruan tinggi Indonesia menurut pendapat menghadapi masalah pembiayaan yang tidak kalah atau bahkan lebih serius dari yang dihadapi oleh PT di Negara-negara Eropa, paling tidak perguruan tinggi di Negara-negara seperti inggris sudah memiliki infrasatruktur kelembagaan dan sumber daya manusia yang cukup kuat.Sebaliknya, kelembagaan serta pembiayaan perguruan tinggi Indonesia masih jauh dari memuaskan. Anggaran pendidikan tinggi pada tahun 2002 dan 2003 misalnya hanya sekitar Rp. 4,3 sampai 5 triliun atau sekitar 0,3 sampai 0,4 persen Produk Nasional Bruto (PDB), jauh lebih rendah dari Negaranegara lain. Biaya pendidikan yang tersedia semakin kecil karena kebijakan nasional adalah 
menaikkan anga Partisipasi Kasar Pendidikan Tinggi hamper dua kali lipat dalam 5 tahun terakhir, dari 8 persen menajdi 15 persen pada Propenas 20002004. Kebijakan perluasan angka partisipasi ini membawa dampak langsung terhadap pembiayaan pendidikan tinggi.Biaya merata per mahasiswa mengalami penurunan 50 persen daolam waktu kurang dari 5 tahun.Penurunan biaya yang cukup drastis ini membawa implikasi yang amat besar pada mutu Pendidikan tinggi. Di UGM, misalnya, Pengeluaran Pemerintah untuk Pendidikan Tinggi pada tahun 2003 hanya berjumlah Rp. 5,2 juta per mahasiswa. Menurut perhitungan sementara, biaya pendidikan di Prodi non-eksakta adalah Rp. 8,5 juta per mahasiswa per tahun, Rp 9,9 juta di Prodi eksakta, dan Rp. 12,1 juta di prodi kedokteran dan kesehatan. Di Malaysia, pengeluaran pemerintah untuk pendidikan tinggi berjumlah Rp. 83 juta per mahasiswa dan di beberapa universitas di Australia mencapai Rp. 96-138 juta per mahasiswa per tahun. Karena pembiayaan yang amat rendah ini amat mustahil bagi para pengelola Perguruan Tinggi Indonesia untuk mempertahankan mutu pendidikannya. Memang ada tuduhan yang dilontarkan oleh berbagai pihak, antara lain oleh pengamat pendidikan tinggi Prof. Dr. Ki Supriyoko, yang menghubungkan kemerosotan mutu perguruan tinggi Indonesia dengan Praktek-praktek program "Kelontong", "executive class", dan "off-campus" program. Saya kira ranking rendah yang diperoleh perguruan tinggi Indonesia di bandingkan dengan perguruan tinggi Asia lainnya, seperti yang terekam pada survey Perguruan Tinggi Asia yang dilakukan oleh Majalah Asianwek edisi 2001, lebih disebabkan oleh rendahnya gaji dosen, kecilnya anggaran pendidikan, penelitian dan perpustakaan, serta tersedianya fasilitas pendukung seperti laboratorium yang canggih serta pusat layanan teknologi infoemasi yang mutakhir.

Pada saat kondisi keuangan Pemerintah amat berat karena harus menyediakan porsi anggaran yang besar untuk subsidi BBM, bahan pangan serta untuk membayar hutang, nampaknya Pemerintah tidak akan mugnkin meningkatkan alokasi anggaran untuk pendidikan, khususnya pendidikan tinggi. Pada saat ini anggaran pemerintah untuk pendidikan masih jauh di bawah standar UNESCO, hanya sekitar 0,7 persen dari PDB. Karena kondisi yang seperti ini, kita sebagai pengelola perguruan tinggi harus berani melakukan pergeseran paradigmatik (paradigm shift) dalam pembiayaan pendidikan tinggi.Sudah saatnya masyarakat, khususnya para mahasiswa menyadari, bahwa pembiayaan pendidikan tinggi bukan hanya sematamata tanggung jawab Pemerintah, tetapi juga adalah tanggung jawab masyarakat.Akses kelompok ekonomi lemah memang harus tetap dipertahankan tetapi bukan dengan mempertahankan biaya pendidikan murah, tetapi melalui subsidi silang, program beasiswa, serta dengan membuka kesempatan kerja paruh waktu di kampus.

a. Perubahan Populasi Calon Mahasiswa
Masuk Keperguruan Tinggi.

Beberapa perguruan tinggi besar di Indonesia sering kali mendapat teguran dari pembuat kebijakan karena dituduh telah melakukan "cardinal sin" membuka program off-campus.Bahkan teguran sudah sedemikian sengitnya, sampai-sampai ada Edaran kepada berbagai Departemen dan BUMN oleh seorang pejabat Depdiknas yang menyatakan bahwa gelar yang diberikan oleh suatu lembaga pendidikan 
tinggi tidak sah.Kontroversi semacam ini belum menunjukan tandatanda akan menurut dalam waktu dekat sebelum para pejabat tersebut memahami perubahan yang sedang terjadi dalam peta calon mahasiswa yang masuk ke perguruan tinggi.

Globalisasi yang sedang melanda berbagai bagian dunia telah mendorong perkembangan knowledge society dan knowledge based economy. Perkembangan inilah yang oleh Alvin Toffler disebut sebagai Gelombang Industri Ketiga, yang dimulai dengan pertumbuhan pesat industry yang berbasis ilmu pengetahuan dan teknologi, khususnya teknologi informasi.Di Negara berkembang seperti Indonesia, ada tanda-tanda industry Gelombang Pertama, kedua dan ketiga terjadi tanpa harus menunggu siklus Gelombang Industri sebelumnya selesai. Dengan kata lain, pada ekonomi Gelombang Pertama-industri pertanianGelombang Kedua-manufakturing-masing berlangsung.

Perkembangan Industri Gelombang Kedua dan Ketiga ini telah mendorong Pemerintah dan dunia usaha untuk meningkantkan pengetahuan para pegawainya.Perkembangan ini membawa dampak yang amat besar pada populasi calon mahasiswa perguruan tinggi. Pada dekade 70-an populasi calon mahasiswa di dominasi oleh para lulusan SMTA. Pada decade 90-an jumlah calon mahasiwa lulusan program sarjana yang meemrlukan pendidikan pasca sarjana mengalami kenaikan yang amat pesat, mencapai hampir 15-20 persen dari total populasi mahasiswa. Karena working force yang memerlukan pelayanan pendidikan tinggi ini mungkin mereka dipaksa datang ke kampus-kampus perguruan tinggi untuk mengikuti

kelas-kelas
konvensional.Perguruan tinggi harus cermat menangkap perubahan yang sedang terjadi di masyarakat dan berusaha memenuhi permintaan masyarakat tersebut. Kalau perguruan tinggi tidak cepat tanggap atau dihalanghalangi oleh birokrasi yang kaku dalam memenuhi tuntutan masyarakat tersebut, kebutuhan mereka akan dipenuhi oleh lembagalembaga lain yang kurang bertanggung jawab. Menurut pendapat saya, tumbuhnya lembaga pendidikan tinggi yang "menjual" gelar-gelar kesarjanaan, juga dipersubur oleh sikap pemerintah yang kurang memahami perkembangan yang sedang terjadi di masyarakat.

b. Disparitas Perguruan Tinggi Antar Daerah Di Indonesia.

Saat ini kepercayaan masyarakat kepada pemerintah dan lembaga politik national berada pada titik nadir terendah.Kerena itu masyarakat sekarang berpaling kepada perguruan tinggi sebagai lembaga yang masih memiliki kekuatan moral untuk menjadi panutan masyarakat dalam transformasi menuju masyarakat madani.Mampukah lembaga perguruan tinggi menjalankan misi yang amat penting tetapi suci ini, pada saat lembaga kita ini tidak sepenuhnya terbebaskan dari kelemahan dan kekuran pada masyarakat transisitional?Saya kira tidak ada jawaban yang mudah terhadap pernyataan ini.

Menurut pengamatan saya, dunia perguruan tinggi kita belum memiliki kekuatan moral yang kuat untuk menjadi panutan masyrakat, karena dalam transformasi menuju masyarakat madani, kita belum mampu mengembangkan diri menjadi model ideal masyarakat madani yang ber-ketuhan-an, menghargai supremasi hukum, demokratis, 
berkeadaban, adil, sertabertanggung jawab.

Kesenjangan kualitas perguruan antar daerah dan antar perguruan tinggi negeri dan swasta dapat kita lihat dari berbagai akuran, jumlah dosen yang berpendidikan S-3, kualitas fasilitas pendukung seperti laboratorium, kebun kebun percobaan, perpustakaan yang memadai, serta aksesstaf dan mahasiswa ke imternet. Saya pernah mencoba membandingkan UGM dengan beberapa perguruan tinggi di Negara tetangga dalam fasilitas perpustakaan dan akses ke internet.Sistem perpustakaan UGM pada saat ini memiliki koleksi buku sebanyak 400.000buku dan 600 jurnal. Dibeberapa perguruan tinggi di Negara tetangga, seperti National University of Singapora, Seoul National University atau Universitas Beijing, koleksi buku sudah mencapai diatas 2,5 juta buku dengan anggaran perpustakaan yang lebih dari 5persen dari anggaran Universitas.akseske jaringan internet internasional di UGM, bila diukur dengan besarnya bandwidth, baru mencapai 1,5 Mbps. Fasilitas internet di university of Malaysia sudah memiliki bandwidth sebesar 14 Mbps. Di National University of singapure mencapai 100 mbps, tetapi Universitas Xinhua di China bahkan sudah memiliki bandwidth sebesar 1 Gbps untuk memfasilitasi akses kejaringan Internet bagi seluruh dosen dan mahasiswanya. Disperitas perguruan tinggi di Indonesia pada saat ini masih cukup besar, bila diukur dalam kualitas dosen, anggaran kualitas fasilitas pendukung, serta akses kejaringan internet.

\section{Mengelolah Perguruan Tinggi Menghadapi Tantangan Dan Perubahan}

Bagaimana mengelola sebuah
perguruan tinggi agar mampu menghadapi berbagai tantangan global tadi dengan selamat? Sebagai suatu organisasi dengan anggota yang mempunyai tingkat pendidikan yang reata lebih tinggi dari masyarakat pada umumnya, perguruan tinggi seharusnya dapat menjadi organisasi yang terdepan dalam menghadapi berbagai tantangan global sayangnya berbeda dengna harapan orang banyak, perguruan tinggi tidak terlalu berbeda dengan organisasi pemerintah daerah dalam persiapan menghadapi perubahan.

Ransformasi pengelolaan UGM agar mampu merespons berbagai tantangan global bertambah intensif sejak perguruan tinggi ini ditetapkan oleh Depdiknas sebagai PT BHMN bersama UI, IPB dan ITB.Sejak itu langkah-langkah stratejik telah dilakukan oleh Universitas Gajah Mada adalah untuk meningkatkan kemampuan Universitas menjalankan fungsi Tridharma pendidikan tinggi.Reformasi yang dilaksanakan mencakup perumusan kembali misi universitas, restrukturisasi kelembagaan dan diversifikasi pembiayaan. Agar mudah mengingatnya kami namakan upaya tersebut Reformasi Misi,Reformasi Kelembagaan, dan Reformasi Finansial.

Reformasi Misi UGM adalah langkah-langkah stratejik yang dilakukan untuk merealisasikan Visi UGM menjadi Universitas penelitian yang mendapat pengakuan internasional pada 2010.Untuk merealisasikan visi ini, perlu dilakukan penataan terhadap struktur program studi internalisasi paradikma student-learning dan penerapan system pengadilan mutu pada semua srata program studi.Langkah awal yang sedang kami lakukan adalah menata kembali 
komposisi populasi mahasiswa di UGM. Pada saat ini mahasiswa UGM telah mencapai 50.000 orang, yang terdiri atas 19,1 persen mahasiswa pasca sarjana, 64,2 persen mahasiswa program S1 dan profesi,dan 16,7 persen mahasiswa program diploma. Sebagai langkah awal penataan menuju Universitas Penelitian dan sebagai upaya meningkatkan kualitas program diploma,akan dilakukan pemisahan manajemen terhadap program diploma.

Untuk menyuburkan tumbuhnya budaya student-learning, sejak awal para mahasiswa program S-1,S-2, dan S-3 akan dilibatkan dalam penelitian-penilitian yang dilakukan oleh para pembimbingnya. Proses pembelajaran yang konvensional secara bertahap akan ditinggalkan dan diganti dengan proses proses pembelajaran yang lebih mendorong pembelajaran secara aktif oleh para mahasiswa.

Dalam rangka lebih mendorong tercapainya budaya pembelajaran, sekarang mulai diterapkan sistim pengendalian mutu yang bertujuan untuk memantau seberapa jauh proses penerimaan mahasiswa. Proses pembelajaran dan proses mempersiapkan lulusan sesuai dengn standar internasional. Kerja keras yag dilakukan oleh tim pengendali mutu yang bernaung dibawah wakil rector dibidang pendidikan dan pengendalian mutu telah mulai menunjukan hasi-hasil yang mengembirakan, bila dilihat dari hasil program studi yang diakreditasi oleh badan Akreditasi Nasional, yang memperoleh penilaian positif dari lembagalembaga penilaian indipenden, mupun dari prestasi memenangkan kompetensi dana penelitian dari pemerintah.
Restrukturisasi kedua yang belum selesai dilaksanakan adalah reformasi kelembagaan reformasi ini mencakup penyusunan kembalisemua peraturan untuk melaksanakan statute baru Universitas Gajah Mada (PP.No.153 Tahun 2000), pembentukan kelengkapan organ PT-BHMN, khususnya pembentukan Majelis Wali Amanat yang merupakan Governing Body dan pembentukan dewan Audit, pembentukan pimpinan Universitas dimulai dengan pemilihan rektor dan pengangkatan 5 Wakil Rektor, pembentukan senat Akademik, dan pembentukan Majelis Guru Besar. Semua kelengkapan PTBHMN ini sudah berfungsi dengan baik.

Restrukturisasi kelembagaan ini akan dilanjutkan dengan pembentukan Senat Akademik Fakultas, pemberian peranan yang lebih besar pada jurusan, Bagian dan Laboraturium sebagai ujung tombak pelaksanaan fungsi perguruan tinggi. Penetapan jangka panjang adalah merestrukturisasi organisasi fakultas dengan menggabungkan beberapa fakultas yang berkaitan bidang ilmunya. Universitas British Columbia, misalnya baru-baruini menggabungkan Fakultas Pertanian, Fakultas Kehutanan,Fakultas Teknologi Pertanian dan Fakultas Perikanan menjadi Fakultas Sumber Daya Alam (faculty of Natural Resources) namun, langkah restrukturisasi ini harus dilakukan dengan hati-hati dan dengan mempertimbangkan berbagai implikasi pisikologis dan financial yang akan ditimbulkannya.

Untuk meningkatkan pelaksanaan Universitas penelitian pada saat ini sedang dikembangkan konsep Research SSchool dengan memungkinkan pusatpusat penelitian yang qualified untuk menyelenggarakan program pasca 
sarjana dibawah naungan program pasca sarjana. Tiga pusat penelitian sedang mengalami reviu secara intensif pada saat ini dalam proses mendapatkan izin dari senat akademik.

Reformasi Finansial merupakan upaya restrukturisasi yang amat besar tantangannya.Ada dua masalah besar yang terkait dengan pembiyayaan pendidikan tinggi.Pertama, biaya merata pendidikan di UGM berbeda jauh dibawah standar internasional. Menurut perhitungan sementara, biaya rerata pendidikan per mahasiswa di UGM berkisar antara Rp. 8,5 juta per mahasiswa per tahun untuk fakultas noneksata sampai Rp. 12,1 juta untuk fakultas kedokteran dan kesehatan. Di Australia, biaya rata-rata per mahasiswa sudah mencapai Rp. 96 juta sampai Rp. 138 juta. Kedua, subsidi pemerintah dan unuversitas per mahasiswa masih tinggi, berkisar antara 77 persen untuk setiap mahasiswa fakultas non-eksata sampai 80 persen untuk mahasiswa fakultas kedokteran.

Menghadapi kenyataan ini, pimpinan universitas harus melakukan langkah menerapkan biaya pendidikan yang lebih rasional. Secara gradual biaya pendidikan akan disesuaikan agar akhirnya sesuai dengan standar internasional. Mulai tahun akademik 2003 akan diperkenalkan skema "fullpaying" untuk dari para calon dari keluarga ekonomi mampu yang lulus dalam ujian saringan. Universitas juga sedang mengusahakan pembentukan dana abadi dan mengembangkan reksadana Gadjah Mada sebagai bentuk divesifikasi sumber pembiayaan.

Harus disadari bahwa reformasi financial yang akan menyebabkan kenaikan SPP atau pun biaya pendidikan akan menghadapi protes yang keras dari kelompok mahasiswa yang menganut pradigma "pendidikan murah untuk semua" tetapi Universitas harus terus menyadarkan masyarakat kampus bahwa masa-masa emas pembiayaan pendidikan oleh pemerintah sudah berada diujung perjalanan dan masyarakat harus mau berpartisipasi dalam pembiayaan pendidikan tinggi. Kalau langkah tidak populer ini tidak berani kita lakukan, perguruan tinggi Indonesia akan meluncur cepat menuju jurang kehancuran.

Langkah reformasi yang sedang berlangsung di UGM tidak berjalan tanpa hambatan seperti halnya yang dialami oleh ITB, penyesuaian structural di UGM menghadapi berbagai hambatan internal maupun eksternal.Hambatan internal paling utama adalah besarnya resistansi internal terhadap reformasi misi, reformasi kelembagaan maupun reformasi financial.Rasistansi internal ini nampaknya berakar pada "mindsed" masyarakat kampus yang khawatir akandampak negatif dari perubahan sehingga tidak mudah menerima langkahlangkah pembaharuan.

Keinginan pemerintah untuk mendorong otonomi perguruan tinggi yang dimulai pada 4 perguruan tinggiUI,IPB,ITB dan UGM-nampaknya masi menghadapi kendala legal dan procedural yang cukup besar. Otonomi perguruan tinggi pada dasarnya adalah pelimpahan kewenangan akademik, kewenangan personil dan kewenangan financial pada PTN.Dalam pelaksanaanya, kewenangan personil belum dilimpahkan sepenuhnya kepada PT-BHMN sampai hari ini, kewenangan rektor BHMN masih sebatas pengangkatan pegawai negeri sampai 
pangkat III/d atau rektor.Di atas golongan tersebut tetap merupakan kewenangan Departemen.Upayah untuk melimpahkan kewenangan kepegawaian ke PTBHMN nampaknya masi menghadapi kendala legal karna instansi Pembina kepegawaian- BKN-menganggap bahawa pimpinan PT-BHMN bukanlah yang berwenang melaksanakan fingsi kepegawaian.

Pelimpahan kewenangan keuangan juga masih menghadapi berbagai kendala legal maupun procedural. Secara legal, bentuk PT berbadan hokum milik negara belum dikenal dalam undang-undang keuangan negara dan undang perbendaharaan negara yang berlaku. Akibatnya, pengelokasian anggaran kepada PTBHMN tetap mengikuti prosedur yang berlaku yakni siklus perencanaan dan pengangguran untuk instansi pemerintah (DIK dan DIKS) serta siklus perencanaan dan pengganggaran pembangunan (DIP).

Karena hambatan internal dan eksternal tersebut, implementasi kebijakan ppengembangan otonomi perguruan tinggi tidak berjalan seperti diharapkan.Untuk mengatasi hambatanhambatan eksternal perlu dilakukan terobosan hokum pada tingkat departemen melalui pelimpahan kewenangan kepegawaian kepada pimpinan PT-BHMN. Untuk mengatasi hambatan legal dan procedural keuangan, mungkin dapat dikeluarkan Surat Keputusan Bersama (SKB) menteri keuangan dan Mentri Pendidikan Nasional tentang pengelolaan keuangan PT-BHMN, sambil menunggu terbitnya UU keuangan negara, UU perbendaharaan negara dan UU pendidikan tinggi yang mengatur tentang PT-BHMN pembebanan bantuan umum dan bantuan khusus untuk PT-BHMN pada anggaran penerimaan dan belanja negara, serta sistim keuangan PT=BHMN. Kalau pelimpahan kewenangan keuangan dan kepegawaian tidak diberikan, pelaksanaan otonomi perguruan tinggi pasti akan terganggu dan hanya sekedar pemberian otonomi setengah hati.

\section{Kesimpulan}

Sebegai pimpinan perguruan tinggi bahwa untuk langkah-langkah struktural adjustment yang diperlukan dalam rangka mempersiapkan perguruan tinggi masing-masing menghadapi tantangan-tantangan global hanya mungkin dilakukan bila kepada perguruan tinggi diberikan otonomi pengelolaan yang lebih besar.Kebijakan nasional pengembangan PT seperti yang tertuang dalam Propenas 2000-2004 sebenarnya sudah menuju kea rah yang benar.

Tetapi pemberian otonomi perguruan tinggi melalui pembentukan PTBHMN masih menghadapi kendala internal dan eksternal yang cukup kuat, yang kalau tidak diatasi akan mempengaruhi kinerja kebijakan restrukturisasi PT. Agar kibijakan otonomi PT mampu mencapai outcomes seperti yang diharapkan, para pimpinan perguruan tinggi harus mampu mengatasi resistensi internal terhadap gebrakangebrakan reformasi yang dilakukan dalam rangka pembinaan otonomi PT. disamping itu, para pembuat kebijakan di tingkat departemen harus, bersama dengan pimpinan PT, harus mampu mengurangi hambatan eksternal melalui penerbitan kerangka peraturan perundangan yang lebih kondusif untuk pertumbuhan PT-BHMN sebagai wahana pengembangan otonomi perguruan tinggi. 


\section{Rekomendasi}

1. Manajemen perguruan tinggi perlu dikelolah secara komprehensif dengan melibatkan pihak komponen yang ada di dalamnya.

2. Mampu memanfaatkan sumber daya yang memahami teknologi informasi dalam lingkungan perguruan tinggi.

3. Perlu ada kerja sama dengan perguruan tinggi lainnya baik di dalam negeri maupun di luar negeri.

\section{Daftar Pustaka}

Beck, U, What is Globalization? Cambridge. Polity Press, 2000

Effendi, Sofian. Revitalizing Higher Education for Sustainaiunable Economic Growth,Paper read at Indonesia-German Symphosium 2002. Aaachen. RWTH, July 29, 2002

Jarvis, Peter. Universities and Corporate Universities:The Higher Learning Industries in Globalization,London Kogan page Industies, 2001

Kadiman, Kuemayanto, Tantangan dan Kendala Yang DihadapilTB Sebagai BHMN, Makalah dibacakan pada seminar Nasional Majelis Rektor Wilayah Barat. Bandung. Institut Teknologi Bandung, 2002

Renner, K. Edward, The New Agenda For Higher Education, Calgary. Detselig Enterprises, Ltd., 1995

Scott, P. (Ed), TheGlobalization Of Higher Education, Buckingham.Open University Press, 1988

Stiglitz, Joseph P, Globalization and Its Discontents,New York. W.W Norton \& Company, 2002

Universitas Gajah Mada. Rencana Stratejik 2002-2007.Yogyakarta. Universitas Gajah Mada 